\title{
PENERAPAN METODE PENDUGAAN AREA KECIL (SMALL AREA ESTIMATION) PADA PENENTUAN PROPORSI RUMAH TANGGA MISKIN DI KABUPATEN KLUNGKUNG
}

\author{
Putu Eka Ariwijayanthi ${ }^{1}$, I Wayan Sumarjaya ${ }^{2}$, \\ TJOKORDA BAgUS OKA ${ }^{3}$ \\ ${ }^{1,2,3}$ Jurusan Matematika FMIPA Universitas Udayana, Bukit Jimbaran-Bali \\ e-mail: ${ }^{1}$ ari_math09@yahoo.com, ${ }^{2}$ sumarjaya@unud.co.id, ${ }^{3}$ tjokordabagusoka@ gmail.com
}

\begin{abstract}
Small area is an area with insufficient sample for direct estimation. Limited survey objects, cause direct estimation can not produce better parameter estimates. Based on this, an indirect estimation method called empirical Bayes is used to obtain a better estimate. This study will compare means squared error by direct estimation method and empirical Bayes method to find a better method on a small area. Jackknife is used to get the means squared error in the empirical Bayes. The results is, empirical Bayes methods give a better parameters based on mean squared errors. Empirical Bayes can produce a smaller mean squared error more than direct estimation in small area.
\end{abstract}

Keywords: Pendugaan Area Kecil, Bayes Empirik, Jackknife

\section{Pendahuluan}

Survei penduduk merupakan salah satu cara yang digunakan untuk memperoleh informasi mengenai kependudukan. Penerapan sistem sampel dalam survei penduduk pada area yang kecil menyebabkan objek survei menjadi terbatas. Keterbatasan objek survei menyebabkan pendugaan langsung tidak dapat menghasilkan dugaan yang teliti. Guna menghasilkan pendugaan yang lebih baik, maka digunakan metode pendugaan tidak langsung pada area kecil (Rao, [5]).

Pendugaan area kecil merupakan suatu teknik statistika yang digunakan untuk menduga parameter-parameter subpopulasi dengan ukuran sampel yang kecil. Teknik ini mengembangkan data survei dan sensus untuk mengestimasi tingkat kesejahteraan atau indikator lainnya (Rao, [5]).

Salah satu metode yang dapat diterapkan pada area kecil dengan kasus data cacah atau biner yaitu metode Bayes empirik. Metode ini bekerja dengan menggunakan inferensi dari estimasi posterior untuk menentukan dugaan parameter. Metode Bayes empirik memiliki kelebihan yaitu lebih mudah dalam pendugaan parameter dibandingkan dengan Bayes berhierarkhi (Kurnia, [4]). Pendekatan Bayes empirik memiliki karakteristik yaitu: (1) memperoleh fungsi densitas posterior dari parameter area kecil yang teramati, (2) pendugaan parameter model dari fungsi densitas marginal, (3) menggunakan pendugaan

\footnotetext{
${ }^{1}$ Mahasiswa Jurusan Matematika FMIPA Universitas Udayana

${ }^{2,3}$ Staf Pengajar Jurusan Matematika FMIPA Universitas Udayana
} 
fungsi densitas posterior untuk membuat inferensi parameter area kecil (Rao, [5]).

Salah satu distribusi posterior yang digunakan pada metode Bayes empirik yaitu distribusi beta-binomial. Distribusi beta-binomial merupakan distribusi posterior pada metode Bayes Empirik yang memiliki dua tahapan, yaitu tahap pertama diasumsikan bahwa peubah yang menjadi perhatian $y_{i} \stackrel{\text { iid }}{\sim} \operatorname{Bin}\left(n_{i}, \theta_{i}\right), y_{i}=0, \ldots, n_{i}, 0<\theta_{i}<1, i=1, \ldots, m$, sedangkan pada tahap kedua diasumsikan bahwa $\theta_{i} \stackrel{\text { iid }}{\sim} \operatorname{Beta}(\alpha, \beta)$ sebagai prior (Kismiantini, [3]). Guna mengoreksi galat yang dihasilkan pada metode Bayes empirik digunakan metode jackknife.

Pada penelitian ini, digunakan data banyaknya rumah tangga miskin di Kabupaten Klungkung. Berdasarkan data rumah tangga miskin pada masingmasing desa di Kabupaten Klungkung tahun 2011 dilihat dugaan parameter serta perbandingan kuadrat tengah galat yang dihasilkan antara pendugaan langsung dan metode Bayes empirik. Semakin kecil dugaan kuadrat tengah galat yang dihasilkan maka menunjukkan bahwa metode tersebut lebih baik dalam menghasilkan dugaan parameter pada pendugaan area kecil.

\section{Metode Penelitian}

Data yang digunakan pada penelitian ini adalah data sekunder yang diperoleh dari Badan Pemberdayaan Masyarakat dan Pemerintah Desa Provinsi Bali (2011). Data berupa banyaknya rumah tangga miskin setiap desa di Kabupaten Klungkung tahun 2011. Pemilihan Kabupaten Klungkung sebagai lokasi penelitian berdasarkan pertimbangan bahwa Kabupaten Klungkung merupakan salah satu kabupaten yang memiliki pengeluaran rata-rata per kapita per bulan di bawah rata-rata per kapita per bulan Provinsi Bali (Badan Pusat Statistik Provinsi Bali, [2]). Total desa yang dimiliki oleh Kabupaten Klungkung sebanyak 59 desa dengan 43.665 rumah tangga (Badan Pemberdayaan Masyarakat dan Pemerintah Desa Provinsi Bali, [1]).

Langkah-langkah analisis data yang dilakukan mengikuti tahapan: (1) Menghitung dugaan proporsi rumah tangga miskin dari setiap desa di Kabupaten Klungkung kemudian menentukan dugaan kuadrat tengah galat (KTG) dengan pendugaan langsung; (2) Melakukan pendugaan parameter dengan metode Bayes empirik kemudian menentukan dugaan kuadrat tengah galat dengan metode jackknife; (3) Membandingkan dugaan kuadrat tengah galat antara pendugaan langsung dan Bayes empirik.

\section{Hasil dan Pembahasan}

Data yang digunakan dalam penelitian ini adalah data sekunder berupa data banyaknya rumah tangga $\left(n_{i}\right)$ serta banyaknya rumah tangga miskin $\left(y_{i}\right)$ di Kabupaten Klungkung yang berasal dari Badan Pemberdayaan Masyarakat dan Pemerintah Desa Provinsi Bali (2011). Banyaknya rumah tangga di Kabupaten 
Klungkung yang dijadikan sampel dalam penelitian ini sebanyak 10 rumah tangga untuk masing-masing desa (Badan Pusat Statistik, [2]).

\subsection{Metode Pendugaan Langsung}

Metode pendugaan langsung pada area kecil menggunakan distribusi binomial dengan mengasumsikan bahwa rumah tangga miskin adalah kejadian "sukses" dan rumah tangga tidak miskin adalah kejadian "gagal". Pendugaan parameter $\hat{\theta}$ pada metode langsung dengan $y_{i}$ menyatakan banyak sampel rumah tangga miskin dan $n_{i}$ menyatakan sampel rumah tangga adalah:

$$
\hat{\theta}_{i}=\frac{\sum_{i=1}^{n} y_{i}}{n_{i}^{2}}
$$

Kuadrat tengah galat pada pendugaan langsung diperoleh dengan:

$$
\operatorname{KTG}\left(\widehat{\theta}_{i}\right)=n_{i} \widehat{\theta}_{i}\left(1-\widehat{\theta}_{i}\right)
$$

Proporsi yang dihasilkan oleh metode pendugaan langsung dengan sampel rumah tangga miskin sebanyak 10 rumah tangga menghasilkan dugaan parameter sebesar 0,1 rumah tangga dengan kuadrat tengah galat sebesar 0,09. Hal tersebut berarti dugaan proporsi rumah tangga miskin sebesar $10 \%$ menghasilkan error sebesar 0,09 .

\subsection{Metode Pendugaan Tidak Langsung dengan Bayes Empirik}

Pendugaan tidak langsung Bayes empirik untuk menduga parameter serta penentuan kuadrat tengah galat dengan metode jackknife dihitung dengan menggunakan software SAS 9.2. Dugaan parameter $\hat{\alpha}$ pada Bayes empirik yaitu 0,4460423 dan $\hat{\beta}$ sebesar 0,0486287. Berdasarkan dugaan $\hat{\alpha}$ dan $\hat{\beta}$, kemudian diperoleh dugaan parameter Bayes empirik. Dugaan parameter Bayes empirik diperoleh dengan:

$$
\hat{\theta}_{i}^{E B}=\hat{\theta}_{i}^{B}(\hat{\alpha}, \hat{\beta})=\hat{\gamma}_{i} \hat{\theta}_{i}+\left(1-\hat{\gamma}_{i}\right) \hat{\theta}
$$

dengan $\hat{\gamma}_{i}=\frac{n_{i}}{n_{i}+\widehat{\alpha}+\widehat{\beta}} \operatorname{dan} \hat{\theta}=\frac{\widehat{\alpha}}{\widehat{\alpha}+\widehat{\beta}}$.

Kuadrat tengah galat pada Bayes empirik diperoleh dengan metode jackknife, yaitu:

dengan

$$
\mathrm{KTG}_{j a c k}\left(\hat{\theta}_{i}^{E B}\right)=\widehat{M}_{1 i}+\widehat{M}_{2 i}
$$

dan

$$
\widehat{M}_{1 i}=g_{1 i}\left(\hat{\alpha}, \hat{\beta}, y_{i}\right)-\frac{m-1}{m} \sum_{l=1}^{m}\left[g_{1 i}\left(\hat{\sigma}_{v,-i}^{2}\right)-g_{1 i}\left(\hat{\sigma}_{v}^{2}\right)\right]
$$

$$
\widehat{M}_{2 i}=\frac{m-1}{m} \sum_{l=1}^{m^{\prime}}\left[\hat{\theta}_{i,-l}^{E B}-\hat{\theta}_{i}^{E B}\right]^{2} .
$$

Proporsi yang dihasilkan oleh pendugaan Bayes empirik sebesar 0,99537 dengan sampel rumah tangga miskin sebanyak 10 rumah tangga dengan kuadrat tengah galat sebesar 0,0003967. Hal tersebut berarti, suatu desa dengan metode Bayes empirik akan menghasilkan dugaan proporsi rumah tangga miskin sebesar 
99,537\% dan menghasilkan error sebesar 0,0003967.

\subsection{Perbandingan Metode Pendugaan Langsung dan Metode Bayes Empirik Berdasarkan Kuadrat Tengah Galat}

Berdasarkan hasil analisis dengan software SAS 9.2 diperoleh bahwa pendugaan tidak langsung Bayes empirik dengan metode jackknife secara umum mampu meminimumkan error dibandingkan pendugaan langsung. Hal ini dapat terlihat pada nilai kuadrat tengah galat (KTG) Bayes empirik yang lebih kecil. Akan tetapi, pendugaan kuadrat tengah galat dengan Bayes empirik juga menghasilkan beberapa nilai yang lebih besar daripada pendugaan langsung, yaitu pada desa Kampung Toyapakeh, Lembongan, dan Kampung Kusamba. Dugaan kuadrat tengah galat yang dihasilkan oleh desa tersebut disajikan pada Tabel 1.

Tabel 1. Kuadrat Tengah Galat dengan Pendugaan Langsung dan Bayes Empirik dengan Ukuran Sampel Rumah Tangga Miskin 0 dan 1

\begin{tabular}{|l|c|c|c|c|}
\hline \multicolumn{1}{|c|}{ Desa } & $n_{i}$ & $y_{i}$ & $\mathrm{KTG}\left(\hat{\theta}_{i}\right)$ & $\mathrm{KTG}\left(\hat{\theta}_{i}^{E B}\right)$ \\
\hline Kampung Toyapakeh & 10 & 0 & 0 & 0.00325 \\
\hline Lembongan & 10 & 1 & 0.0099 & 0.01018 \\
\hline Kampung Kusamba & 10 & 0 & 0 & 0.00325 \\
\hline
\end{tabular}

Berdasarkan tabel tersebut diperlihatkan bahwa kuadrat tengah galat yang dihasilkan oleh Bayes empirik lebih besar dibandingkan pendugaan langsung. Hal ini karena pendugaan langsung pada beberapa desa menggunakan sampel yang terlalu kecil yang memiliki kemungkinan sampel tersebut tidak mampu mewakili keseluruhan gambaran mengenai populasi di suatu desa.

\section{Kesimpulan}

Berdasarkan hasil yang dipaparkan pada bab sebelumnya, dapat disimpulkan bahwa metode Bayes empirik untuk menduga proporsi rumah tangga miskin di Kabupaten Klungkung memberikan hasil yang lebih baik pada pendugaan area kecil dengan menghasilkan kuadrat tengah galat yang lebih kecil dibandingkan pendugaan langsung, kecuali pada desa dengan banyak rumah tangga miskin $\left(y_{i}\right)$ sebanyak 0 dan 1. Desa tersebut adalah Desa Kampung Toyapakeh, Lembongan, dan Kampung Kusamba dimana metode Bayes empirik menghasilkan kuadrat tengah galat yang lebih besar daripada pendugaan langsung. Hal tersebut dikarenakan ukuran sampel yang terlalu kecil sehingga kemungkinan tidak bisa mewakili keseluruhan populasi. 


\section{Daftar Pustaka}

[1] Badan Pemberdayaan Masyarakat Dan Pemerintah Desa Provinsi Bali. 2011. Persentase Pendataan Program Perlindungan Sosial. BPMPD Provinsi Bali. Bali.

[2] Badan Pusat Statistik. 2011. Pola Konsumsi dan Distribusi Pendapatan Provinsi Bali. BPS Provinsi Bali. Bali.

[3] Kismiantini. 2010. "Penerapan Metode Bayes Empirik Pada Pendugaan Area kecil Untuk Kasus Biner". Seminar Nasional Penelitian, Pendidikan dan Penerapan MIPA. Makalah. Jurusan Matematika FMIPA Universitas Negeri Yogyakarta. Yogyakarta.

[4] Kurnia, A., dan Khairil A.N. 2006. "Prediksi Terbaik Empirik untuk Model Transformasi Logaritma di dalam Pendugaan Area Kecil dengan Penerapan pada Data Susenas". Tesis. Sekolah Pascasarjana Institut Pertanian Bogor. Bogor.

[5] Rao, J.N.K. 2003. Small Area Estimation. John Wiley and Sons. New York. 